Reviu Akuntansi dan Bisnis Indonesia, Vol. 2 No. 1, Hlm: 75-91, Juli 2018

Website: http://journal.umy.ac.id/index.php/rab

\title{
Evaluasi Kebutuhan Pernyataan Standar Akuntansi Keuangan (PSAK) Untuk Industri Gadai Syariah
}

Faradila Kusuma Jati; Muhammad Akhyar Adnan

Program Studi Akuntansi Universitas Muhammadiyah Yogyakarta

I N F O A R T IKEL

\section{Kata Kunci:}

Evaluasi, Gadai Syariah

(Rahn), Faktor-Faktor yang

Mempengaruhi,

Keterbatasan

Jenis Artikel:

Penelitian Empiris

Correspondence:

adnan@umy.ac.id
A B S T RAK

Penelitian ini bertujuan untuk mengetahui sejauh mana dibutuhkan Pernyataan Standar Akuntansi Keuangan (PSAK) untuk industri gadai syariah (rahn) serta kebutuhan penyajian laporan keuangan gadai syariah (rahn) secara terpisah dari konvensional dan sesuai dengan standar. Objek penelitian ini adalah satu Kantor Cabang Pegadaian Syariah dan tiga Unit Cabang Pembantu Pegadaian Syariah. Adapun subjek penelitian ini terdiri dari Pakar Akuntansi Syariah, Praktisi Gadai Syariah, dan regulator yaitu pihak Otoritas Jasa Keuangan (OJK). Penelitian ini bersifat deskriptif kualitatif. Berdasarkan analisis yang telah dilakukan, peneliti menyimpulkan bahwa PSAK untuk indutri gadai syariah adalah dibutuhkan dan penyajian laporan keuangan secara terpisah dan sesuai dengan standar harus dilakukan. Faktor-faktor yang menyebabkanPSAK tersebut dibutuhkan diantaranya adalah pada asek kepatuhan syariah, kebutuhan akan pencatatan dan penyajian laporan keuangan yang dapat dipertanggungjawabkan kepada para pemangku kepentingan, pegadaian syariah berhubungan langsung dengan masyarakat luas, memberikan panduan bagi pembuat kebijakan untuk membuat aturan yang benar sekaligus melakukan pengawasan dan memacu pertumbuhan bisnis gadai syariah. Penyajian laporan keuangan pegadaian syariah yang terpisah dengan konvensional dan sesuai dengan standar harus dilakukan untuk mencegah kekeliruan yaitu tercampurnya yang haqdan yang bathil.

(C) 2019 RAB. Published by Universitas Muhammadiyah Yogyakarta

\section{PENDAHULUAN}

Lembaga Keuangan Syariah (LKS) adalah lembaga keuangan yang mengeluarkan produk keuangan syariah dan mendapatkan izin operasionalnya sebagai LKS. Berdasarkan pengertian tersebut dapat diketahui bahwa LKS harus memiliki dua unsur dalam menjalankan aktivitasnya, pertama adalah kesesuaian LKS dengan syariah Islam dan kedua adalah legalitas operasi sebagai sebuah lembaga keuangan (Yaya dkk, 2014). Dunia akuntansi memerlukan sebuah standar antara lain disebabkan oleh banyak pengguna informasi keuangan tersebut digunakan untuk membuat keputusan ekonomi.

Tiap-tiap pihak mempunyai keperluan yang berbeda dalam menggunakan informasi keuangan. Informasi keuangan sebagai kriteria untuk menilai performa perusahaan. Standar yang digunakan dalam akuntansi adalah Pernyataan Standar Akuntansi Keuangan (PSAK). Ada lima hal yang diatur dalamnya yaitu:

1. Definisi

2. Pengakuan 
3. Pengukuran

4. Penyajian

5. Pengungkapan

Perkembangan LKS di Indonesia sangatlah pesat dengan bermunculannya kegiatan bisnis yang menggunakan prinsip syariah dalam kegiatannya, salah satunya adalah Gadai Syariah. Lembaga Keuangan yang melakukan bisnis gadai syariah diantaranya adalah Pegadaian Syariah PT. Pegadaian (Persero) dan Perbankan Syariah. Adanya pegadaian syariah bermula dari perkembangan LKS yang ada di Indonesia. Pegadaian syariah adalah salah satu lini bisnis syariah dari PT. Pegadaian (Persero) yaitu lembaga keuangan non-bank yang dimiliki oleh pemerintah dan dalam menjalankan usahanya menggunakan sistem gadai syariah (Rahmawati, 2016).

Menurut Razak dkk. (2017) gadai syariah (ar-rahn) adalah salah satu instrumen keuangan syariah yang berpotensi dalam mempromosikan inklusi keuangan. Inklusi keuangan sendiri diartikan sebagai sebuah pola berpikir para pelaku ekonomi terhadap cara pandang mereka terhadap uang. Pada pola pikir lama, ketika melihat uang maka yang terpikir adalah bagaimana cara untuk mendapatkan keuntungan yang besar, namun dengan pola pikir inklusi keuangan maka mereka melihat keuntungan bukan semata dari nominal uang namun pada kesejahteraan para pelaku ekonomi tersebut dan ikut andil dalam pengentasan kemiskinan (dosen.perbanas.id).

Di Indonesia terjadi dualisme pegadaian yaitu yang dilakukan oleh PT. Pegadaian (Persero) dan dilakukan oleh pihak bank. Untuk PT. Pegadaian (Persero) menerima gadai emas dan barang berharga lain juga ada produk-produk lain yang ditawarkan, sedangkan pada bank syariah hanya menerima gadai emas saja (Setiawan, 2016). Tidak menutup kemungkinan pihak swasta mendirikan usaha gadai syariah di Indonesia setelah dikelurkannya Peraturan Otoritas Jasa Keuangan (POJK) Nomor 31 /POJK.05/2016 mengenai Usaha Pergadaian, maka diperlukan sebuah standar untuk industri gadai syariah.

Dijelaskan bahwa keluarnya POJK tersebut disebabkan karena untuk meningkatkan inklusi keuangan bagi masyarakat menengah ke bawah, memberikan kemudahan akses terhadap pinjaman, dan memberikan landasan hukum yang jelas untuk mengawasi usaha pergadaian tersebut. Dari penjelasan tersebut maka dibuatlah POJK tentang Usaha Pergadaian dimana dengan adanya POJK ini akan membuat bermunculan perusahaan gadai syariah swasta yang legal di Indonesia.

Berkembangnya usaha gadai syariah di Indonesia menyebabkan dibutuhkannya suatu standar akuntansi yaitu PSAK khusus untuk gadai syariah agar terjadi keselarasan dalam industri tersebut yang didalamnya diatur mengenai definisi, pengakuan, pengukuran, penyajian, dan pengungkapan dari gadai syariah $(r a h n)$.

Berikut adalah laporan kinerja bisnis gadai syariah PT. Pegadaian (Persero) yang dilaporkan di annual report tahun 2016:

Tabel. 1.1 Kinerja Bisnis Gadai Syariah

\begin{tabular}{llll}
\hline Uraian & Realisasi 2015 & Realisasi 2016 & Naik (Turun) \% \\
\hline Nasabah (orang) & 823.980 & 854.182 & $3,67 \%$ \\
Rekening (ribuan potong) & 1.017 & 1.110 & $9,14 \%$ \\
Omzet (jutaan rupiah) & 13.077 .842 & 14.894 .349 & $7,79 \%$ \\
$\begin{array}{l}\text { Outstanding Pinjaman yang diberikan } \\
\text { (jutaan rupiah) }\end{array}$ & 3.198 .977 & 3.665 .558 & $14,59 \%$ \\
Pendapatan sewa modal (jutaan rupiah) & 840.037 & 921.769 & $9,73 \%$ \\
\hline
\end{tabular}

Sumber: pegadaian.co.id

Jumlah nasabah PT. Pegadaian (Persero) untuk Syariah Business Unit (SBU) yang tahun 2017 menjadi UUS adalah sebanyak 854.182 orang atau 9,6\% dari total nasabah PT. Pegadaian (Persero) yaitu sebanyak 8.907.368 orang berdasarkan annual report 2016. Menurut Purbasari \& Rahayu (2017) Pegadaian Syariah menerapkan rahn sebagai akad utama dan mengenakan biaya administrasi yang ditentukan berdasarkan jumlah pinjaman. Berdasarkan konsep, akad rahn adalah 
akad tambahan dan bukan merupakan akad utama. Pengenaan biaya administrasi berdasarkan jumlah pinjaman juga menimbulkan isu transaksi yang mengandung riba.

Menurut Purbasari \& Rahayu (2017) Pegadaian Syariah menerapkan rahn sebagai akad utama dan mengenakan biaya administrasi yang ditentukan berdasarkan jumlah pinjaman. Berdasarkan konsep, akad rahn adalah akad tambahan dan bukan merupakan akad utama. Pengenaan biaya administrasi berdasarkan jumlah pinjaman juga menimbulkan isu transaksi yang mengandung riba.

Untuk gadai emas syariah yang ada di Indonesia, terdapat keraguan dari berbagai kalangan mengenai kesyariahan praktik gadai emas syariah dengan konsep yang ada. Berbagai opini menyatakan bahwa praktik gadai emas syariah masih sama saja dengan gadai emas konvensional (Sofi'i, 2017).

Sistem syariah diharapkan mampu memberikan ketenangan bagi masyarakat dalam memperoleh pinjaman secara benar dan halal sesuai syariah Islam. Beda gadai syariah dengan konvensional adalah tidak dikenakannya bunga atas pinjaman yang diberikan.

Pada akuntansi syariah tidak mengandung maysir (spekulasi), gharar (ketidakpastian), riba (tambahan yang memberatkan) dan bathil (haram menurut ketentuan agama), sedangkan pada akuntansi konvensional masih terdapat bunga (Rahman \& Suprayogi, 2015). Untuk gadai emas syariah yang ada di Indonesia, terdapat keraguan dari berbagai kalangan mengenai kesyariahan praktik gadai emas syariah dengan konsep yang ada. Berbagai opini menyatakan bahwa praktik gadai emas syariah masih sama saja dengan gadai emas konvensional (Sofi'i, 2017).

Perlakuan akuntansi rahn yang dilakukan di Pegadaian Syariah menggunakan prinsip akuntansi yang berlaku umum karena belum ada standar akuntansi yang berlaku untuk pembiayaan rahn (Isini \& Karamoy, 2017). Menurut Bahari dkk. (2015) salah satu upaya penting untuk memastikan lembaga gadai syariah ini dapat bertahan di pasar keuangan syariah adalah dengan adanya standar dan regulasi yang pasti mengenai hal tersebut.

Peraturan perlakuan akuntansi gadai yang belum ada standarnya tersendiri khusus gadai syariah memungkinkan terjadi kecurangan dalam perlakuan akuntansinya (Rahman \& Suprayogi, 2015). Berdasarkan pada aspek yang diatur dalam PSAK salah satunya adalah penyajian saat ini untuk penyajian laporan keuangan Pegadaian Syariah PT. Pegadaian (Persero) belum dilakukan pemisahan dalam publikasi laporan keuangan tersebut sehingga belum dapat terlihat apakah laporan keuangan yang disajikan sudah sesuai standar akuntansi syariah.

Apabila laporan keuangan yang disajikan masih menggunakan standar yang sama untuk pembuatan laporan keuangan konvensional maka hal ini menjadi keliru. Dalam laporan keuangan konvensional ada pos-pos yang tidak sama dalam hal pengakuan dalam laporan keuangan, hal tersebut dapat membuat tercampurnya yang haq dan yang bathil. Hal ini disebabkan belum adanya PSAK yang mengatur khusus untuk industri gadai syariah.

Berdasarkan penelitian yang dilakukan Rahman \& Suprayogi (2015) penyajian dan pengungkapan pada pegadaian syariah belum sesuai dengan PSAK 100 tentang Kerangka Dasar Penyusunan dan Penyajian Laporan Keuangan Syariah (KDPLKS) dan PSAK 101 tentang Penyajian Laporan Keuangan Syariah. Hal tersebut disebabkan karena transaksi syariah harus disajikan secara tersendiri pada laporan keuangan dan tidak bergabung menjadi satu dengan konvensional.

Menurut Muhammad (2014) penggabungan dalam hal ini adalah laporan keuangan dari pegadaian syariah dapat menimbulkan persoalan syariah berupa tercampurnya yang haq dan yang batil. Pertanggungjawaban kesyariahan dari kegiatan operasional maupun dalam perlakuan akuntansi dalam gadai syariah merupakan salah satu perwujudan dari Qur'an Surah Al-Muddassir ayat 38 , Allah berfirman :

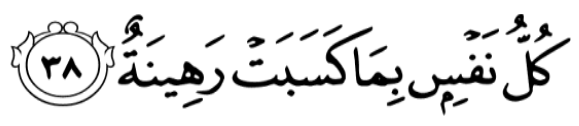

"Setiap orang bertanggung jawab atas apa yang telah diperbuatnya." 
Dari penjabaran di atas bahwa masih terdapat keraguan dalam kesyariahan kegiatan bisnis gadai syariah dan juga belum adanya standar akuntansi baku untuk gadai syariah, maka alangkah baiknya apabila hal tersebut segera diakhiri dengan adanya standar yang dapat menampung kegiatan bisnis dari industri gadai syariah yang sesuai dengan syariah unuk meminimalkan keraguan atas akad yang dipakai dalam gadai syariah. Adanya standar maka akan terjadi keselarasan dalam menjalankan bisnis gadai syariah antara pihak satu dengan lainnya baik dari segi operasional maupun dari sudut pandang akuntansi.

Selain itu agar Lembaga Keuangan Syariah (LKS) dalam hal ini gadai syariah menjadi benarbenar melaksanakan kegiatan bisnisnya sesuai dengan syariah seperti yang diinginkan tentunya oleh nasabah dan pertanggungjawaban kepada Allah SWT nantinya jelas karena tidak hanya membawa nama syariah di belakangnya namun kenyataannya juga menerapkan syariah dalam kegiatannya.

\section{TINJAUAN LITERATUR DAN PERUMUSAN HIPOTESIS}

\section{Teori Institusional}

Teori Institusional didasari pada pemikiran bahwa untuk bertahan hidup, organisasi harus dapat meyakinkan pada masyarakat atau publik bahwa organisasi merupakan entitas yang sah dan layak untuk mendapat dukungan (Meyer \& Rowan, 1977). Teori institusional memberikan penjelasan bagaimana mekanisme suatu organisasi melakukan aktivitasnya sesuai dengan nilai-nilai sosial dan budaya yang melingkupinya (Isgiyarta, 2009).

Teori institusional menjadi salah satu perspektif teoritis yang dominan dalam teori organisasi dan semakin banyak diterapkan dalam penelitian akuntansi untuk mempelajari praktik akuntansi dalam organisasi (Dillard dkk, 2004). Memperluas fokus Teori Institusional berdasarkan penelitian akuntansi dapat memudahkan representasi komprehensif yang lebih dari akuntansi sebagai objek praktik institusional serta menyediakan artikulasi yang lebih baik dalam peran akuntansi dalam proses pelembagaan (Dillard dkk, 2004). Hal tersebut menjelaskan bahwa Gadai Syariah harus mendapat dukungan dari pemerintah dan regulator agar dapat bertahan di pasar keuangan syariah. Bentuk dukungan terhadap gadai syaiah adalah dengan adanya realisasi standar akuntansi keuangan untuk gadai syariah itu sendiri.

\section{Teori Agensi}

Teori agensi adalah teori yang berfokus pada prinsipal dan agen. Informasi akuntansi dalam teori agensi salah satunya digunakan untuk mengambil keputusan oleh prinsipal. Apabila prinsipal tidak dapat mengamati usaha agen secara langsung maka hal ini dapat berakibat pada agen melakukan hal yang berbeda dengan yang seharusnya dilakukan. Menurut Herawaty (2009) angkaangka dalam laporan keuangan diharapkan bisa meminimalkan perbedaan pendapat antara para pihak yang berkepentingan. Hal diatas menjelaskan bahwa gadai syariah harus mempunya standar akuntansi sendiri khusus gadai syariah sehingga setiap kegiatan yang dilakukan dalam gadai syariah sesuai dengan standar. Dengan adanya standar maka gadai syariah dapat melaporkan laporan keuangan sesuai dengan standar yang ada dan kebijakan yang diambil untuk gadai syariah tidak tercampur dengan konvensional.

\section{Transparansi Pelaporan Keuangan}

Menurut Stiglitz (1999) akuntabilitas dan transparansi adalah hak asasi bagi setiap manusia. Menurut Heise (1985) dalam Rawlins (2008) mendefinisikan transparansi yaitu upaya sengaja untuk menyediakan seluruh informasi yang dapat dirilis secara legal baik positif maupun negatif dengan akurat, seimbang, tepat waktu, tegas, yang bertujuan untuk meningkatkan kemampuan penalaran publik dan mempertanggungjawabkan tindakan yang dilakukan organisasi, kebijakan serta praktik oganisasi. Transparansi pelaporan keuangan berhubungan dengan standar akuntansi keuangan 
untuk gadai syariah, dengan adanya standar akuntansi untuk gadai syariah maka gadai syariah dapat melakukan kegiatannya sesuai dengan standar khususnya pada perlakuan akuntansi gadai syariah dan melaporkan laporan keuangan gadai syariah sesuai standar dan terpisah dari gadai konvensional agar terlihat transparansi dari gadai syariah tersebut dan informasi keuangan tersebut dapat dikonsumsi oleh stakeholder.

\section{Evaluasi}

Evaluasi adalah mengambil keputusan berdasarkan kriteria atau standar ( Gunawan \& Palupi, 2016). Evaluasi merupakan salah satu ranah dari taksonomi bloom oleh Benjamin S. Bloom, M.D. Engelhart, E. Furst, W.H. Hill, dan D.R. Krathwohl, yang kemudian didukung pula oleh Ralph W. Tyler (Putra, 2016). Evaluasi adalah menentukan nilai materi dan metode untuk tujuan tertentu. Evaluasi bersangkutan dengan penentuan secara kuantitatif atau kualitatif tentang nilai materi atau metode untuk suatu maksud dengan memenuhi tolok ukur tertentu (Gunawan \& Palupi, 2016). Mengukur lebih bersifat kuantitatif, sedangkan menilai lebih bersifat kualitatif (Anggraini, 2017).

Tabel 2.1. Kategori Taksonomi Anderson dan Kratwohl

\begin{tabular}{|c|c|c|c|}
\hline \multicolumn{4}{|r|}{ Mengevaluasi } \\
\hline & Kategori & Kata Kunci & Penjelasan dan Contoh \\
\hline & Memeriksa & $\begin{array}{l}\text { Mengoordinasi, } \\
\text { Mendeteksi, } \\
\text { Memonitor, } \\
\text { Menguji }\end{array}$ & $\begin{array}{l}\text { Menemukan kesalahan dalam suatu proses atau produk; } \\
\text { menemukan efektivitas suatu prosedur yangs edang dipraktikkan } \\
\text { (misalnya memeriksa apakah kesimpulan seseorang sesuai dengan } \\
\text { data-data pengamatan atau tidak) }\end{array}$ \\
\hline 2. & Mengkritik & Menilai & $\begin{array}{l}\text { Menemukan inkonsistensi antara suatuproduk dan kriteria } \\
\text { eksternal; menentukan apakah suatu produk memiliki konsistensi } \\
\text { eksternal, menemukan ketepatan suatu prosedur untuk } \\
\text { menyelesaikan masalah (misalnya, menentukan suatu metode dari } \\
\text { dua metode untuk menyelesaikan suatu masalah). }\end{array}$ \\
\hline
\end{tabular}

Sumber: (Anderson dan Kratwohl, 2001).

Evaluasi adalah proses penilaian. Penilaian ini bisa menjadi netral, positif atau negatif atau merupakan gabungan dari keduanya. Saat sesuatu dievaluasi biasanya orang yang mengevaluasi mengambil keputusan tentang nilai atau manfaatnya (Anggraini, 2017). Kategori evaluasi dibedakan menjadi dua, yakni: (1) evaluasi berdasarkan bukti internal yaitu evaluasi terhadap ketetapan komunikasi berdasarkan logika, konsistensi, dan kriteria-kriteria internal lain misalnya, menunjukkan kesalahan-kesalahan logika dalam suatu argumen; dan (2) evaluasi berdasarkan bukti eksternal yaitu evaluasi terhadap materi berdasarkan kriteria yang ditetapkan atau diingat, misalnya membandingkan teori-teori, generalisasi-generalisasi, dan fakta-fakta pokok tentang kebudayaan tertentu (Gunawan, 2016). Evaluasi dilakukan pada gadai syariah mengenai kebutuhan gadai syariah terhadap Pernyataan Standar Akuntansi Keuangan (PSAK) khusus untuk industri gadai syariah. Berdasarkan evaluasi yang dilakukan nantinya didapatkan kesimpulan mengenai sejauh mana dibutuhkannya PSAK untuk industri gadai syariah.

\section{Prinsip Akuntansi Berterima Umum (PABU)}

PABU adalah suatu rerangka pedoman yang terdiri atas standar akuntansi dan sumbersumber lain yang didukung berlakunya secara resmi (yuridis), teoretis, dan praktis. PABU digunakan sebagai kriteria kewajaran penyajian statemen keuangan. Alasan pertama mengapa PABU digunakan sebagai kriteria kewajaran penyajian statemen keuangan adalah tidak semua ketentuan perlakuan akuntansi dapat atau telah dituangkan dalam bentuk standar akuntansi (Suwardjono, 2005).

Dari gambar dibawah diketahui bahwa PABU terdiri dari dua yaitu standar akuntansi dan praktik yang sehat. Di dalamnya dijelaskan mengenai kewajaran penyajian. Kewajaran penyajian 
juga harus dievaluasi secara luas atas dasar ketentuan-ketentuan lain yang mengikat. Termasuk dalam ketentuan lain adalah peraturan perundang-undangan dan ketentuan-ketentuan oleh badan selain penyusun/penetap standar. Alasan kedua adalah bila standar akuntansi secara eksplisit/tegas dijadikan kriteria dan dinyatakan dalam laporan auditor, dikhawatirkan terjadi adalah kewajaran hanyalah bersifat formal bukan bersifat substantif. Artinya standar akuntansi akan dijadikan standar minimal dan ada kemungkinan evaluator atau auditor hanya memenuhi standar minimal tersebut untuk menentukan kewajaran. Dapat terjadi hal-hal penting yang tidak diatur dalam standar akuntansi tidak dipertimbangkan secara seksama atau bahkan diabaikan. Kemudian alasan ketiga yaitu untuk mencapai kualitas informasi yang tinggi, ukuran kewajaran harus merupakan suatu rerangka pedoman yang cukup komprehensif/menyeluruh meliputi aspek teknis dan konseptual. Terdapat tiga istilah yang saling berkaitan yaitu prinsip akuntansi, standar akuntansi dan PABU.

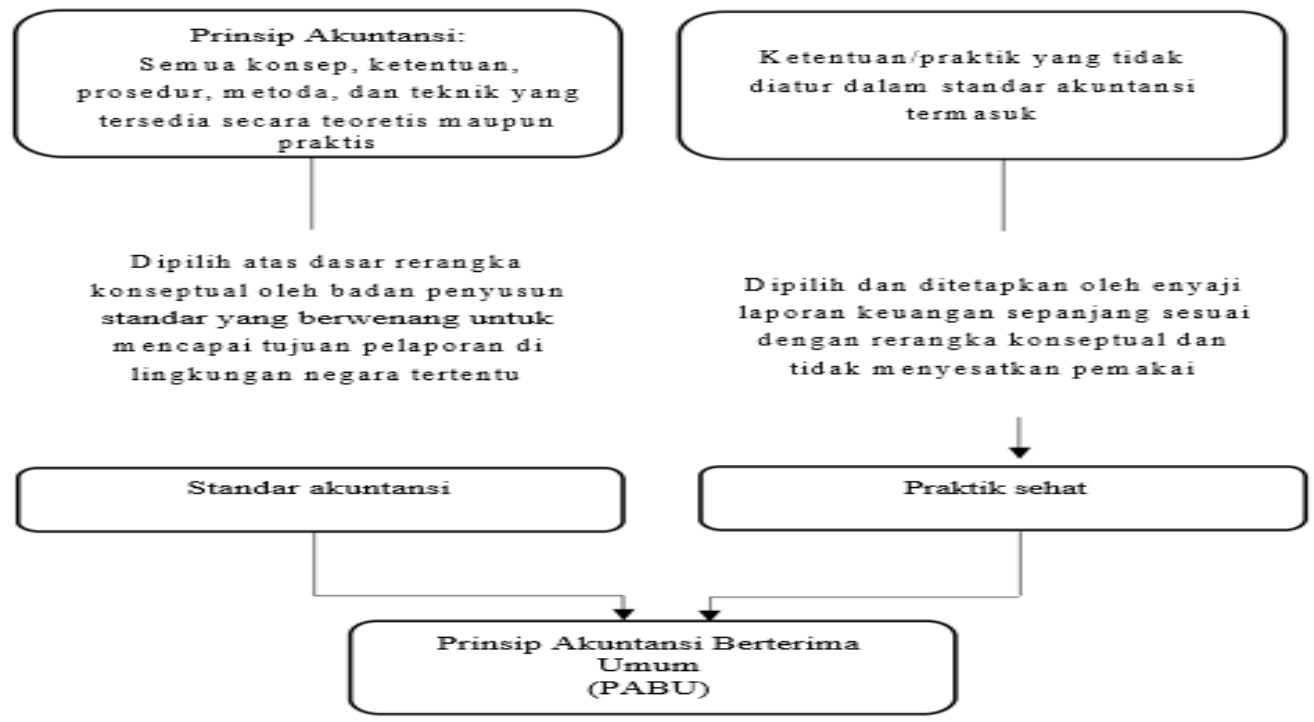

Gambar 2.1 Hubungan Prinsip Akuntansi, Standar Akuntansi, dan PABU

\section{Gambaran Umum Gadai Syariah}

Menurut Ali (2008), gadai ( $r a h n)$ adalah menahan barang gadai atau disebut dengan jaminan yang bersifat materi dan memiliki nilai ekonomis milik rahin sebagai jaminan atas pinjaman yang diterimanya, sehingga murtahin memiliki jaminan untuk mengambil kembali hutangnya dari barang gadai tersebut, apabila pihak berhutang tidak dapat membayar kewajiban pada waktunya. Menurut Purbasari \& Rahayu (2017) jaminan pada gadai syariah ini memiliki tujuan untuk mendapatkan kepercayaan dari pihak yang memberikan pinjaman. Fungsi dari ar-rahnu menurut Bahari dkk. (2015) adalah untuk melayani pelanggan yang membutuhkan modal langsung atau tunai dengan cara gadai emas atau perhiasan yang mereka miliki kepada pihak pegadaian syariah. Pengertian arrahn menurut istilah adalah menahan sejumlah harta yang dijaminkan atas manfaat yang didapatkan yaitu berupa uang hasil taksiran barang jaminan tersebut yang nantinya dapat diambil kembali manfaatnya setelah dibayar kembali uang pinjaman tersebut. Rasulullah juga pernah melalukan gadai yaitu untuk memberi makan seorang yahudi dan beliau menggadaikan baju besinya, yaitu dalam hadist riwayat Aisyah RA, beliau berkata:

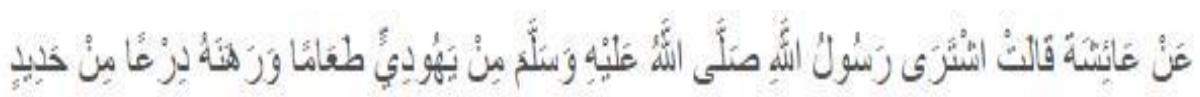

"Rasulullah SAW pernah membeli makanan dari seorang Yahudi dengan cara menangguhkan pembayarannya, lalu beliau menyerahkan baju besi beliau sebagai jaminan”. 
Menurut Sofi’i (2017) pada dasarnya fungsi dari gadai adalah memberikan bantuan pada orang yang membutuhkan. Barang jaminan yang diberikan digunakan sebagai jaminan utang dan tidak digunakan untuk mengambil keuntungan yang besar. Tujuan adanya praktik gadai syariah adalah untuk memberikan pinjaman atau pembiayaan dengan cara yang benar dan halal sehingga menghindarkan masyarakat dari meminjam dana ke lintah darat, pegadaian gelap atau pinjaman yang tidak wajar lainnya. Menurut Soemitra (2009) pegadaian syariah dalam menjalankan operasionalnya berpegang kepada prinsip syariah. Pada dasarnya, produk-produk berbasis syariah memiliki karakteristik seperti, tidak memungut bunga dalam berbagai bentuk karena riba, menetapkan uang sebagai alat tukar, dan melakukan bisnis untuk memperoleh imbalan atas jasa dan/atau bagi hasil.

\section{Konsep Ar-Rahnu}

Menurut Bhatt \& Sinnakkannu (2008) terdapat kombinasi dari empat konsep yang digunakan oleh gadai syariah yaitu:

\section{a. Qardhul Hasan}

Lembaga Keuangan akan memberikan pinjaman yang baik (tanpa bunga) kepada pemohon yang ingin menjaminkan barang berharga miliknya. Pinjaman yang dikeluarkan berdasarkan konsep qardhul hasan mengharuskan peminjam membayar hutangnya dengan jumlah yang sama guna menebus barang jaminan pada saat jatuh tempo pada periode yang disepakati. Pengertian qardhul hasan dalam bank syariah menurut Adnan \& Furywardhana (2006) adalah salah satu hal yang membedakan antara syariah dengan konvensional, dikarenakan didalamnya terdapat misi sosial kepada masyarakat dan nantinya meningkatkan citra baik dan loyalitas nasabah menjadi meningkat.

\section{b. Wadiah Yad-Amanah}

Peminjam diharuskan menyerahkan agunan yang dapat dikembalikan untuk memastikan pelunasan pinjaman. Peminjam mempercayakan yang memberikan pinjaman untuk mengurus barang-barang selama masa pinjaman. Jika kejadian yang tidak terpikirkan terjadi pada item jaminan bukan karena kelalaian pemberi pinjaman, pemberi pinjaman tidak diharuskan untuk mengganti barang tersebut.

c. Al-Ujrah

Konsep ini menyatakan bahwa pihak yang memberi pinjaman diperbolehkan untuk mengenakan biaya yang masuk akal untuk layanan yang diberikan agar barang jaminan aman dan dalam kondisi baik. Lembaga keuangan menerima hak atas memelihara/menyimpan aset berharga tersebut dalam konsep wadiah dimana LKS berjanji untuk menyimpan aset berharga di tempat yang aman dan kembali ketika waktunya tiba. Lembaga pemberi pinjaman mengambil tindakan pencegahan seperti memberikan keamanan dan asuransi untuk memastikan pengembalian yang aman setelah pelanggan membayar hutangnya. Berdasarkan konsep wadiah, LKS akan membebankan pelanggan untuk layanan yang diberikan dengan menjaga aset berharga.

\section{d. Wadiah Yadhomanah}

Pihak yang memberi pinjaman akan bertanggung jawab untuk mengganti barang yang hilang/dicuri pada pemiliknya apabila pemberi pinjaman gagal mematuhi kesepakatan tersebut karena kelalaiannya sendiri. Manfaat sistem transaksi gadai syariah yaitu:

a. Berdasarkan prinsip syariah yang merupakan bentuk bebas bunga pinjaman.

b. Lebih mudah dan keamanan terjamin. 
c. Biaya lebih murah dari gadai konvensional.

d. Biaya penyimpanan tetap.

e. Jangka waktu pembiayaan lebih panjang.

f. Tidak ada denda

g. Dilakukan lelang dan ada kelebihan, maka akan dikembalikankepda peminjam.

\section{Ketentuan Hukum Gadai Syariah}

Menurut Soemitra (2009) transaksi gadai menurut syariah haruslah memenuhi rukun dan syarat, yaitu:

a. Rukun gadai

1) Ada ijab dan kabul

2) Ada pihak yang berakad, yaitu pihak yang menggadaikan (rahin) dan yang menerima gadai (murtahin)

3) Ada jaminan (marhun) berupa barang atau harta

4) Ada utang (marhun bih).

b. Syarat sah gadai

1) Rahin dan murtahin dengan syarat-syarat yaitu kelayakan seseorang untuk melakukan transaksi pemilikan, setiap orang yang sah melakukan jual beli sah melakukan gadai.

2) Sighat dengan syarat tidak boleh terkait dengan masa yang akan datang dan syarat-syarat tertentu.

3) Utang (marhun bih) dengan syarat harus merupakan hak yang wajib diberikan atau diserahkan kepada pemiliknya, memungkinkan pemanfaatannya bila sesuatu yang terjadi utang itu tidak dapat dimanfaatkan maka tidak sah, harus dapat dihitung jumlahnya, bila tidak dapat diukur, rahn itu tidak sah.

4) Barang (marhun) dengan syarat harus bisa diperjualbelikan, harus berupa harta yang bernilai, marhun harus bisa dimanfaatkan secara syariah, diketahui keadaan fisiknya, dan harus dimiliki oleh orang yang melakukan gadai setidaknya harus seizin pemiliknya.

Sedangkan berakhirnya akad rahn menurut Anshori (2006) apabila:

a. Barang jaminan yang diserahkan sudah kembali kepada pemiliknya.

b. Rahin telah menunaikan kewajinbannya yaitu membayar hutang.

c. Barang jaminan dijual berdasarkan perintah hakim atas perintah rahin disebabkan rahin tidak dapat membayar hutangnya.

d. Pembebasan hutang dengan cara apapun, meskipun rahin rahin tidak memberikan persetujuan.

Di samping itu, ada beberapa Fatwa DSN-MUI yang mengatur mengenai gadai syariah diataranya adalah:

a. 25/DSN-MUI/III/2002 tentang Rahn

b. 26/DSN-MUI/III/2002 tentang Gadai Emas Syariah.

c. 68/DSN-MUI/III/2008 tentang Rahn Tasjily

d. 92/DSN-MUI/IV/2014 tentang Pembiayaan yang disertai Rahn

Sedangkan untuk PSAK yang digunakan sebagai pedoman gadai syariah adalah PSAK 107 mengenai Ijarah 


\section{Pernyataan Standar Akuntansi Keuangan (PSAK) Syariah}

\section{a. Pengertian}

Pernyataan Standar Akuntansi Keuangan (PSAK) Syariah merupakan kerangka dasar penysunan dan penyajian laporan keuangan syariah yang disusun oleh Dewan Standar Akuntansi Syariah Ikatan Akuntan Indonesia (DSAS-IAI). Proses akuntansi yang dimulai dengan mengidentifikasi kejadian kemudian transaksi sampai dengan menyajikannya dalam laporan keuangan, memerlukan kerangka dasar penyusunan dan penyajian laporan keuangan. Kerangka konseptual akuntansi membutuhkan suatu sistem yang terikat dengan tujuan serta sifat dasar yang mengarah kepada standar yang konsisten yang terdiri dari batasan, sifat dan fungsi dari laporan keuangan dan akuntansi keuangan ( Nurhayati \& Wasilah, 2014).

Kerangka konseptual ini diharapkan menghasilkan standar dan aturan yang disusun atas dasar yang sama yang diharapkan dapat menambah pengetahuan dan kepercayaan pihak pengguna laporan keuangan tersebut. Adanya kerangka konseptual ini juga dapat dilakukan pembandingan antara satu perusahaan dengan perusahaan lainnya dan pada periode yang berbeda pula. Menurut Suwardjono (2005) hal-hal yang diatur dalam PSAK adalah:

\section{1) Definisi}

Penjabaran mengenai standar tersebut, yaitu berpa elemen,pos, atau objek statemen keuangan atau istilah yang digunakan dalam pelaporan keuangan agar tidak terjadi kesalahan klasifikasi oleh penyusun dan kesalahan interpretasi oleh pemakai.

\section{2) Pengakuan}

Pengakuan didefinisikan sebagai pencatatan suatu jumlah rupiah (kos) ke dalam sistem akuntansi sehingga jumlah tersebut akan mempengaruhi suatu pos dan terefleksi dalam laporan keuangan. Hal ini berhubungan dengan masalah apakah suatu trasaksi dicatat (dijurnal) atau tidak.

3) Pengukuran

Pengukuran didefinisikan sebagai penetuan jumlah rupiah yang harus dilekatkan pada suatu objek yang terlihat dalam suatu transaksi keuangan.

4) Penyajian

Penyajian adalah menetapkan tentang cara-cara melaporkan elemen atau pos dalam seperangkat statemen keuangan agar elemen atau pos tersebut cukup informatif.

5) Pengungkapan

Pengungkapan adalah berkaitan dengan cara penjelasan hal-hal informatif yang dianggap penting dan bermanfaat bagi pemakai selain apa yang dapat dinyatakan melalui statemen keuangan utama.

b. Tujuan

Menurut Nurhayati \& Wasilah (2014), keberadaan kerangka dasar ini bertujuan untuk digunakan sebagai acuan oleh:

1) Penyusun standar akuntansi keuangan syariah dalam melaksanakan tugasnya, dalam hal ini adalah pihak Ikatan Akuntan Indonesia (IAI)

2) Penyusun Laporan Keuangan, yaitu akuntan dan manajer

3) Auditor 
4) Para pemakai laporan keuangan

\section{Penelitian Terdahulu Mengenai Gadai Syariah}

Sudah dilakukan beberapa penelitian mengenai gadai syariah di Indonesia. Penelitian tersebut antara lain oleh Putri (2015) yang melakukan analisis terhadap perlakuan akuntansi rahn pada PT. BSM, Tbk. Cabang Pontianak. Dalam penelitian tersebut dijelaskan bahwa gadai syariah ada yang menggunakan FBI (fee based income) dan ada yang menggunakan mudharabah.

Penelitian lainnya dilakukan oleh Priliana (2015) menganailis mengenai kesesuaian penerapan rahn pada pegadaian syariah PT. Pegadaian Syariah Cabang Jember berdasarkan pada PSAK 102 dan PSAK 107. Hasil penelitian Priliana diketahui bahwa dalam transaksinya, pegadaian tersebut menggunakan akad qardhul hasan, akad rahn, dan akad ijarah. Penerapan akuntansi rahn sudah sesuai dengan PSAK 107, tetapi ada perbedaan pada pengakuan pembiayaan rahn pada PSAK 107 diakui sebagai piutang rahn namun di pegadaian syariah diakui sebagai pinjaman yang diberikan.

Selanjutnya adalah penelitian oleh Setiawan (2016) dijelaskan bahwa di Indonesia terjadi dualisme pegadaian yaitu yang dilakukan oleh PT. Pegadaian (Persero) dan dilakukan oleh pihak bank. Untuk PT. Pegadaian (Persero) menerima gadai emas dan barang berharga lain juga ada produk-produk lain yang ditawarkan, sedangkan pada bank syariah hanya menerima gadai emas saja.

Isini \& Karamoy (2017) melakukan evaluasi mengenai penerapan gadai syariah pada PT. Pegadaian (Persero) pada cabang Manado berdasarkan pada Fatwa DSN-MUI mengenai rahn dan PSAK 107 untuk transaksi sewa ujroh. Hasil penelitian Isini diketahui bahwa Pegadaian Syariah Cabang Manado dalam penerapan dan perlakuan akuntansi telah sesuai dengan PSAK 107 dan Fatwa DSM-MUI, namun untuk keuntungan yang diperoleh pegadaian syariah tersebut belum diketahui oleh umum dikarenakan belum dilakukan publikasi atas laporan keuangan pegadaian syariah tersebut.

Penelitian yang dilakukan oleh Purbasari \& Rahayu (2017) mengenai analisis penerapan akad rahn dan pengenaan biaya administrasi di Kantor Cabang Pegadaian Syariah Pamekasan, dijelaskan bahwa sebenarnya gadai syariah (rahn) adalah akad tambahan, bukanlah akad utama. Hal tersebut berbeda dengan praktiknya yaitu digunakan sebagai akad utama namun diperbolehkan oleh para ulama. Di sini, akad dalam gadai syariah ada tiga yaitu qardh, rahn, dan ijarah. Namun untuk kantor cabang yang diteliti hanya menerapkan akad ijarah dan akad rahn, sedang terdapat penyimpangan yaitu besarnya biaya administrasi disesuaikan dengan golongan pinjaman.

Penelitian yang telah dilakukan sebatas pada evaluasi penerapan akuntansi gadai syariah yang dilakukan pada PT. Pegadaian (Persero), namun belum pada evaluasi kebutuhan PSAK untuk industri gadai syariah. Dari penelitian sebelumnya, diketahui bahwa terdapat beberapa hal yang tidak sesuai dengan penerapan PSAK yang saat ini sebagai acuan kegiatan bisnis gadai syariah dikarenakan akad pada gadai syariah adalah akad rahn, juga belum adanya laporan keuangan gadai syariah yang dipublikasi ke masyarakat. Dari fakta diatas maka standar yang digunakan saat ini oleh gadai syariah belum mencukupi untuk meng cover kegiatan tersebut dan dibutuhkan standar tersendiri yaitu PSAK gadai syariah.

\section{METODE PENELITIAN}

Objek dalam penelitian ini adalah Kantor Cabang Pegadaian Syariah di Semarang dan Unit Pegadaian Syariah di Yogyakarta. Subjek dalam penelitian ini ada tiga pihak yang pertama adalah pakar akuntansi syariah, kemudian praktisi gadai syariah dan terakhir adalah pihak Otoritas Jasa Keuangan (OJK) perwakilan Daerah Istimewa Yogyakarta (DIY). Metode analisis data yang digunakan dalam penelitian ini adalah metode analisis deskriptif. Menurut Sugiyono (2014) langkah-langkah dalam analisis data pada penelitian kualitatif adalah: 


\section{Data Reduction (Reduksi Data)}

Metode reduksi data yaitu metode yang dilakukan dengan mempersempit pokok bahasan, memfokuskan pada hal-hal penting, mencari tema dan pola kemudian menyisihkan yang tidak perlu.

\section{Data Display (Penyajian Data)}

Langkah selanjutnya setelah reduksi data yaitu menyajikan data. Data disajikan biasanya dalam bentuk paparan singkat, tabel, flowchart dan lain sebagainya.

\section{Verification (Verifikasi/Penarikan Kesimpulan)}

Setelah langkah penyajian data, selanjutnya adalah penarikan kesimpulan dan verifikasi. Kesimpulan awal yang dibuat masih bersifat sementara, dan dapat berubah apabila tidak ditemukannya bukti kuat yang mendukung pada tahap pengumpulan selanjutnya.Kesimpulan awal dikatakan terpercaya apabila didukung oleh bukti yang valid dan konsisten saat peneliti berada di lapangan dan melakukan pengumpulan data

\section{HASIL DAN PEMBAHASAN}

Pada penelitian ini, Pakar Akuntansi Syariah yang berhasil dijadikan sebagai informan adalah enam Dosen yang mengajar di bidang Akuntansi Syariah. Informasi lengkap untuk para pakar yang dijadikan sebagai informan dapat dilihat pada tabel berikut.

Tabel 3.1 Data Informan Pakar Akuntansi Syariah

\begin{tabular}{llllll}
\hline No & Informan & $\begin{array}{l}\text { Pendidikan } \\
\text { Terakhir }\end{array}$ & Lembaga/Instansi & $\begin{array}{l}\text { Dosen } \\
\text { (Jurusan) }\end{array}$ & $\begin{array}{l}\text { Lama } \\
\text { (Tahun) }\end{array}$ \\
\hline 1. & PAS1 & S3 & STEI Hamfara & Akuntansi & 15 \\
2. & PAS2 & S3 & UIN Yogyakarta & Akuntansi & 17 \\
3. & PAS3 & S3 & UMY & Akuntansi & 22 \\
4. & PAS4 & S3 & UII & Akuntansi & 14 \\
5. & PAS5 & S2 & UII & Akuntansi & 31 \\
6. & PAS6 & S2 & UNDIP & Akuntansi & 8 \\
\hline
\end{tabular}

Sumber: data diolah primer

Pada penelitian ini, Praktisi Gadai Syariah yang berhasil dijadikan sebagai informan adalah empat orang. Informasi lengkap untuk para praktisi yang dijadikan sebagai informan dapat dilihat pada tabel berikut.

Tabel 3.2. Data Informan Praktisi Gadai Syariah

\begin{tabular}{lllll}
\hline No & Informan & Pendidikan Terakhir & Lembaga/Instansi & $\begin{array}{l}\text { Lama } \\
\text { (Tahun) }\end{array}$ \\
\hline 1. & PGS1 & S1 & Pegadaian Syariah PT. Pegadaian (Persero) & 2 \\
2. & PGS2 & S1 & Pegadaian Syariah PT. Pegadaian (Persero) & 20 \\
3. & PGS3 & S1 & Pegadaian Syariah PT. Pegadaian (Persero) & 21 \\
4. & PGS4 & S1 & Pegadaian Syariah PT. Pegadaian (Persero) & 2 \\
\hline
\end{tabular}

Sumber: data diolah primer

Pada penelitian ini, pihak OJK yang berhasil dijadikan sebagai informan adalah satu orang. Informasi lengkap untuk pihak OJK yang dijadikan sebagai informan dapat dilihat pada tabel berikut. 
Tabel 3.3 Data Informan dari Regulator

\begin{tabular}{llll}
\hline Informan & $\begin{array}{l}\text { Pendidikan } \\
\text { Terakhir }\end{array}$ & Lembaga/Instansi & $\begin{array}{l}\text { Lama } \\
\text { (Tahun) }\end{array}$ \\
\hline MB & S2 & OJK DIY & 26 \\
\hline
\end{tabular}

\section{A. Evaluasi Kebutuhan PSAK untuk Industri Gadai Syariah Secara Keseluruhan}

Hasil penelitian menunjukkan bahwa terdapat beberapa faktor yang menyebabkan dibutuhkan PSAK untuk Industri Gadai Syariah. Faktor-faktor tersebut dikemukakan oleh Pakar Akuntansi Syariah, Praktisi Gadai Syariah, dan Pihak Otoritas Jasa Keuangan (OJK). Pencatatan dan penyajian Laporan Keuangan dapat dipertanggungjawabkan kepada para pemangku kepentingan, panduan bagi pembuat kebijakan untuk membuat aturan yang benar dan untuk melakukan pengawasan, jaminan kepercayaan masyarakat, aspek kepatuhan syariah dan kemudahan praktisi gadai syariah dalam melakukan pekerjaannya merupakan faktor yang dominan yang menyebabkan dibutuhkan PSAK untuk Industri Gadai Syariah. Hal ini dapat dilihat dalam tabel berikut.

Tabel 3.4 Evaluasi Kebutuhan PSAK untuk Industri Gadai Syariah (Rahn) Secara Keseluruhan

\begin{tabular}{|c|c|c|c|c|c|}
\hline No. & Evaluasi & Pakar & Praktisi & OJK & JML \\
\hline 1. & $\begin{array}{l}\text { Pencatatan dan penyajian Laporan Keuangan dapat } \\
\text { dipertanggungjawabkan kepada para pemangku kepentingan }\end{array}$ & 3 & 2 & 0 & 5 \\
\hline 2. & Berhubungan dengan masyarakat luas & 2 & 0 & & 2 \\
\hline 3. & $\begin{array}{l}\text { Panduan bagi pembuat kebijakan untuk membuat aturan yang } \\
\text { benar dan untuk melakukan pengawasan }\end{array}$ & 2 & 1 & 1 & 4 \\
\hline 4. & Sesuai dengan Prinsip Akuntansi Berterima Umum (PABU) & 1 & 0 & 0 & 1 \\
\hline 5. & Jaminan kepercayaan masyarakat & 2 & 2 & & 4 \\
\hline 6. & Aspek kepatuhan syariah & 5 & 0 & 1 & 6 \\
\hline 7. & Keharusan melakukan spin-off & 1 & 1 & & 2 \\
\hline 8. & $\begin{array}{l}\text { Pengungkapan rekening-rekening dalam laporan keuangan } \\
\text { menjadi jelas }\end{array}$ & 1 & & & 1 \\
\hline 9. & Dukungan pemerintah & 1 & & & 1 \\
\hline 10. & $\begin{array}{l}\text { Kemudahan praktisi gadai syariah dalam melakukan } \\
\text { pekerjaannya }\end{array}$ & 1 & 1 & 0 & 2 \\
\hline 11. & Dapat dilakukan kajian terhadap PSAK Gadai Syariah (Rahn) & 1 & 0 & 0 & 1 \\
\hline 12. & Memacu pertumbuhan bisnis gadai syariah & 2 & 0 & 0 & 2 \\
\hline 13. & Akuntabilitas dalam kegiatan bisnis & 1 & 0 & 0 & 1 \\
\hline 14. & Memberikan kepastian pada industri & 1 & 0 & 0 & 1 \\
\hline Jumla & & 24 & 7 & 2 & 33 \\
\hline
\end{tabular}

Sumber: data diolah primer

Tabel di atas menunjukkan bahwa terdapat 14 faktor yang menyebabkan dibutuhkannya PSAK untuk industri gadai syariah yang dikemukakan oleh ke tiga pihak tersebut baik dari pakar, praktisi, maupun regulator.

\section{B. Pemisahan Laporan Keuangan Gadai Syariah pada Unit Usaha Syariah/Strategic Business Unit PT. Pegadaian (Persero) Secara Keseluruhan}

Hasil penelitian menunjukkan bahwa pemisahan laporan keuangan gadai syariah PT. Pegadaian (Persero) harus dilakukan disebabkan beberapa faktor. Pihak yang mengemukakan mengenai hal tersebut adalah pakar dan praktisi gadai syariah. Faktor dominan tersebut antara lain dapat dilihat kesyariahannya, mengantisipasi persepsi negatif masyarakat terhadap pegadaian syariah dan karakter bisnis berbeda. Faktor-faktor tersebut dapat dilihat 
Tabel 3.5 Pemisahan Penyajian Laporan Keuangan Pegadaian Syariah Secara Keseluruhan

\begin{tabular}{cllll}
\hline No. & Faktor & Pakar & Praktisi & JML \\
\hline 1. & Dapat dilihat kesyariahannya & 4 & 2 & 6 \\
2. & Penegasan regulasi & 1 & 0 & 1 \\
3. & Kemudahan dalam mengukur kinerja keuangan Pegadaian & 1 & 0 & 1 \\
4. Syariah & & & \\
4. & Mengantisipasi persepsi negatif masyarakat terhadap & 2 & 1 & 3 \\
5. & Pegadaian syariah & 1 & 0 & 1 \\
6. & Karaktan laporan keuangan menjadisnis berbeda & 1 & 1 & 2 \\
7. Akuntabilitas Laporan Keuangan & 1 & 0 & 1 \\
Jumlah & 11 & 4 & 15 \\
\hline
\end{tabular}

Sumber: data diolah primer

Tabel di atas menunjukkan bahwa terdapat tujuh faktor yang menyebabkan penyajian laporan keuangan gadai syariah PT. Pegadaian (Persero) harus disajikan terpisah.

\section{Faktor yang Menghalangi Terbentuknya Pernyataan Standar Akuntansi Keuangan (PSAK) untuk Industri Gadai Syariah dan Penyajian Laporan Keuangan Gadai Syariah Secara Keseluruhan}

Hasil penelitian menunjukkan bahwa terdapat keterbatasan atau faktor penghalang yang menyebabkan belum terbentuknya PSAK untuk industri gadai syariah dan belum disajikannya laporan keuangan gadai syariah PT. Pegadaian (Persero). Hal tersebut dikemukakan oleh pakar, praktisi, dan regulator. Faktor yang dominan adalah proses untuk mandiri membutuhkan waktu dan keterbatasan SDM. Faktor-faktor tersebut dapat dilihat pada tabel berikut.

Tabel 3.6 Faktor Penghalang Terbentuknya PSAK untuk Industri Gadai Syariah dan Penyajian Laporan Keuangan Gadai Syariah Secara Keseluruhan

\begin{tabular}{|c|c|c|c|c|c|}
\hline No. & Faktor & Pakar & Praktisi & OJK & JML \\
\hline 1. & Ukuran perusahaan/industri & 2 & 0 & 0 & 2 \\
\hline 2. & Biaya $(\cos t)$ & 1 & 0 & 0 & 1 \\
\hline 3. & Materialitas & 1 & 0 & 0 & 1 \\
\hline 4. & Dasar pembuatan PSAK Syariah & 1 & 0 & 0 & 1 \\
\hline 5. & Pedoman pelaporan keuangan pada praktik bisnis yang lazim & 1 & 0 & 0 & 1 \\
\hline 6. & Proses untuk mandiri membutuhkan waktu & 1 & 1 & 0 & 2 \\
\hline 7. & Keterbatasan SDM & 1 & 1 & 1 & 3 \\
\hline 8. & Adanya PSAK Syariah yang mewadahi akad rahn & 2 & 0 & 0 & 2 \\
\hline 9. & $\begin{array}{l}\text { Belum ada peraturan yang mengharuskan menyajikan laporan } \\
\text { keuangan secara terpisah }\end{array}$ & 1 & 0 & 0 & 1 \\
\hline 10 . & Sudah sesuai dengan Ijma’Ulama & 0 & 1 & 0 & 1 \\
\hline 11. & Aset Pegadaian Syariah belum memenuhi target & 0 & 1 & 0 & 1 \\
\hline 12. & Pegadaian Syariah PT. Pegadaian (Persero) belum spin-off & 0 & 1 & 0 & 1 \\
\hline 13. & $\begin{array}{l}\text { OJK telah memiliki standar tersendiri untuk melakukan tugas } \\
\text { dan wewenangnya pada pegadaian syariah }\end{array}$ & 0 & 0 & 1 & 1 \\
\hline 14. & $\begin{array}{l}\text { Pembuatan standar yaitu PSAK membutuhkan waktu } \\
\text { Jumlah }\end{array}$ & $\begin{array}{l}0 \\
11\end{array}$ & $\begin{array}{l}0 \\
5\end{array}$ & $\begin{array}{l}1 \\
3\end{array}$ & $\begin{array}{l}1 \\
19\end{array}$ \\
\hline
\end{tabular}

Sumber: data diolah primer

Tabel di atas menunjukkan bahwa terdapat 14 faktor yang menghalangi terbentuknya pernyataan standar akuntansi keuangan (PSAK) untuk industri gadai syariah dan penyajian laporan keuangan gadai syariah yang belum terpisah. 


\section{Evaluasi Terhadap Laporan Keuangan Konsolidasian Syariah Kantor Wilayah Semarang PT. Pegadaian (Persero) Bulan Desember 2017 (Neraca dan Laba/Rugi)}

Berdasarkan penelitian yang dilakukan peneliti, diketahui bahwa Pegadaian Syariah PT. Pegadaian (Persero) sudah membuat laporan keuangan terpisah dengan Pegadaian Konvensional. Peneliti berhasil mendapatkan data Laporan Keuangan Konsolidasi Syariah yaitu Neraca dan Laporan Laba/Rugi untuk Kanwil Semarang Bulan Desember 2017. Namun Laporan keuangan Pegadaian Syariah yang terpisah dengan konvensional belum dipublikasi kepada masyarakat.

Laporan keuangan tersebut dibuat oleh Kantor Wilayah. Semua transaksi pegadaian syariah sudah diinput kedalam sistem syariah, namun hasil akhir berupa laporan keuangan yang didapat peneliti, memperlihatkan bahwa laporan keuangan pegadaian syariah tersebut belum menggunakan standar akuntansi syariah dalam penyusunannya. Masih terdapat kekeliruan didalamnya. Seharusnya sebagai entitas syariah, laporan keuangan yang dibuat sesuai dengan standar akuntansi syariah yaitu PSAK syariah minimal adalah sesuai dengan PSAK 101 mengenai penyajian laporan keuangan walaupun belum ada PSAK untuk industri gadai syariah.

Sehubungan dengan fakta tersebut, peneliti akan melakukan evaluasi terhadap laporan keuangan khususnya pada Laporan Laba/Rugi.

1. Pendapatan Denda diakui dalam Pendapatan Usaha

Untuk laporan laba rugi yang dibuat oleh Kanwil Semarang pada pendapatan usaha terdapat pendapatan denda di dalamnya. Apabila denda diakui sebagai pendapatan. Berdasarkan pada Fatwa DSN No. 17/DSN-MUI/IX/2000 Tentang Sanksi Atas Nasabah Mampu Yang MenundaNunda Pembayaran, didalamnya disebutkan beberapa poin yaitu:

a) Sanksi yang disebut dalam fatwa ini adalah sanksi yang dikenakan LKS kepada nasabah yang mampu membayar, tetapi menunda-nunda pembayaran dengan disengaja.

b) Nasabah yang tidak/belum mampu membayar disebabkan force majeur tidak boleh dikenakan sanksi.

c) Nasabah mampu yang menunda-nunda pembayaran dan/atau tidak mempunyai kemauan dan itikad baik untuk membayar hutangnya boleh dikenakan sanksi.

d) Sansi didasarkan pada prinsip ta'zir, yaitu bertujuan agar nasabah lebih disiplin dalam melaksanakan kewajibannya.

e) Sanksi dapat berupa denda sejumlah uang yang besarnya ditentukan atas dasar kesepakatan dan dibuat saat akad ditandatangani.

f) Dana yang berasal dari denda diperuntukkan sebagai dana sosial.

Dari uraian di atas jelas bahwa denda tidak boleh diakui sebagai pendapatan usaha namun diakui sebagai dana kebajikan (qardhul hasan) yang diperuntukkan untuk kegiatan sosial, di dalam Laporan Sumber dan Penggunaan Dana Kebajikan.

Dari data laporan keuangan tersebut diketahui bahwa laporan keuangan konsolidasi syariah kanwil semarang bulan Desember 2017 belum sesuai dengan syariah dan masih menggunakan konsep laporan keuangan konvensional. Seharusnya laporan pegadaian syariah dilaporkan secara terpisah dan sesuai dengan standar akuntansi syariah yang ada walaupun belum ada standar akuntansi syariah untuk gadai syariah.

Dari fakta tersebut, maka adanya penyajian laporan keuangan Pegadaian Syariah secara terpisah dan sesuai dengan standar akuntansi syariah untuk gadai syariah atau PSAK untuk industri gadai syariah sangatlah penting. Didalam syariah tidak boleh ada percampuran antara yang haq dengan yang bathil. Seharusnya dalam lembaga keuangan syariah, denda tidak diakui sebagai pendapatan usaha melainkan diakui sebagai pendapatan non halal dan diperuntukkan untuk kegiatan sosial. 


\section{Ketidak jelasan pos Pendapatan Rahn}

Dalam laporan Laba/Rugi juga belum terlihat untuk pendapatan Rahn Pegadaian Syariah. Yang ada adalah Pendapatan Sewa Modal, dimana pendapatan sewa modal dalam pegadaian konvensional adalah bahasa halus dari bunga yang diterapkan oleh pegadaian konvensional, konteks sewa modal dan bunga adalah sama, yaitu biaya yang dibayarkan oleh nasabah atas pinjaman yang nasabah dapatkan dari pegadaian konvensional. Seharusnya dalam laporan Laba/Rugi tersebut nama posnya bukan Pendapatan Sewa Modal namun Pendapatan Rahn.

Dari fakta tersebut dapat kita ketahui bahwa penyajian laporan keuangan pegadaian syariah masih menggunakan standar atau pedoman dari pegadaian konvensional. Seharusnya hal tersebut tidak dilakukan. Pegadaian syariah seharusnya menyajikan laporan keuangannya sesuai dengan standar akuntansi syariah, walaupun belum ada standar akuntansi yaitu PSAK untuk industri gadai syariah.

Hal ini menjadi salah satu hal yang menjadikan adanya standar yang baku atau pedoman PSAK yang jelas untuk gadai syariah mejadi penting dikarenakan apabila pegadaian syariah tidak menyajikan laporan keuangan sesuai dengan syariah maka lembaga tersebut belum menerapkan syariah pada lembaga keuangan syariah ini. Hal tersebut melanggar aturan syariah dan harus segera dibenarkan.

\section{KETERBATASAN PENELITIAN}

\section{a. Objek Penelitian}

Objek penelitian gadai syariah kurang tergeneralisir dikarenakan hanya pada Pegadaian Syariah PT. Pegadaian (Persero).

\section{b. Informan}

Informan penelitian untuk Praktisi Gadai Syariah hanya pada pegawai Pegadaian Syariah PT. Pegadaian (Persero), Pakar Akuntansi Syariah ada yang belum mendalami gadai syariah sehingga informasi yang didapat terbatas, pihak Otoritas Jasa Keuangan adalah pegawai OJK DIY dimana untuk pengawasan Pegadaian Syariah dilakukan oleh OJK Pusat sehingga informasi yang didapatkan terbatas.

\section{c. Peneliti}

Peneliti masih berstatus sebagai mahasiswa semester akhir yang sedang menyusun skripsi, sehingga dari peneliti sendiri memiliki keterbatasan yaitu pengetahuan peneliti yang sedikit dan pada pertanyaan wawancara yang diajukan peneliti kepada informan masih terbatas dikarenakan pertanyaan tersebut belum terfokus pada rumusan masalah dan banyak pertanyaan yang bersifat umum tidak langsung menjurus pada rumusan masalah penelitian, sehingga informasi yang didapat peneliti juga terbatas.

\section{d. Jenis penelitian}

Penelitian ini bersifat kualitatif sehingga sifatnya lebih pada pemahaman subyek pada keadaan sekitarnya. Sehingga memungkinkan apa yang dikemukakan subyek salah, karena tidak sesuai dengan teori atau tidak sesuai dengan hukum. Peneliti berusaha untuk mendeskripsikan dengan sebenar-benarnya apa yang diperoleh dari hasil wawancara dengan subyek dalam penelitian ini tidak ada yang ditambahkan maupun dikurangi. 


\section{KESIMPULAN}

Secara garis besar, peneliti menyimpulkan untuk kebutuhan PSAK untuk industri gadai syariah adalah dibutuhkan. Gadai syariah memang harus memiliki standar akuntansi agar pencatatan laporan keuangan tersebut bisa dikonsumsi oleh masyarakat, dapat dipertanggungjawabkan kepada stakeholder. Laporan keuangan adalah bahasa bisnis, maka harus bisa dipahami oleh pembuat dan harus dipahami oleh pembaca.

Pembuat harus membuat laporan sesuai dengan standar. Standar akuntansi ini adalah standar untuk memastikan transaksi yang dilakukan itu sudah sesuai dengan ketentuan Allah SWT. Gadai syariah ini juga memerlukan dukungan dari pemerintah, regulasi dari pemerintah menjadi penting dalam pembuatan PSAK untuk gadai syariah. Dalam hal penggabungan laporan keuangan antara Gadai Syariah dengan Gadai Konvensional pada annual report PT. Pegadaian (Persero) tidak dapat dibiarkan begitu saja dikarenakan Pegadaian Syariah dalam proses untuk mandiri. Laporan Keuangan Gadai Syariah harus disajikan dan dilaporkan secara terpisah agar tidak tercampur antara yang haq dan yang bathil. Penggabungan laporan keuangan tersebut tidak mencerminkan entitas syariah.

Terdapat temuan dalam laporan keuangan Pegadaian Syariah PT. Pegadaian (Persero) Kanwil XI Semarang bahwa di dalamnya pada Laporan Laba Rugi Konsolidasi Syariah Pada Pendapatan Usaha terdapat pengakuan atas Pendapatan Denda, pada laporan keuangan tersebut Pendapatan Denda diakui sebagai pendapatan usaha. Hal tersebut keliru dikarenakan seharusnya pendapatan denda tidak diakui sebagai pendapatan usaha namun seharusnya masuk dalam pos dana kebajikan dan dilaporkan dalam laporan sumber dan pnggunaan dana kebajikan.

\section{Saran}

Saran untuk peneliti selanjutnya adalah:

a) Bisa mengembangkan penelitian ini misal dengan menjeneralisir gadai syariah tidak hanya pada Pegadaian Syariah PT. Pegadaian (Persero) saja namun juga dapat ke lembaga gadai syariah lainnya seperti Bank Umum Syariah (BUS).

b) Memperluas informan penelitian dan mencari informan yang benar-benar memahami mengenai gadai syariah, kemudian mencoba untuk menambah informan yaitu dari Pihak IAI maupun OJK yang benar-benar paham mengenai gadai syariah.

c) Peneliti selanjutnya diharap memberikan pertanyaan penelitian yang langsung menjurus pada rumusan masalah penelitian dan lebih dalam ketika melakukan wawancara pada infoman tersebut sehingga mendapatkan informasi yang benar-benar dibutuhkan.

d) PSAK dibagi menjadi dua yaitu PSAK Konvensional dan PSAK Syariah. PSAK Syariah dari 101 dan seterusnya, kalau nantinya dibuat PSAK gadai syariah (rahn) apakah PSAK ini akan sejalan dengan Kerangka Dasar Penyusunan dan Penyajian Laporan Keuangan Syariah (KDPPLK Syariah), maka hal ini perlu diteliti lebih lanjut

\section{DAFTAR PUSTAKA}

Bahari, N. F., Safii, Z., Ahmad, N. W., Fisal, S., \& Shahar, W. S. S. (2015). A Reviews On The Regulation And Conflicting Issues Of Ar Rahnu Operation In Malaysia, In Proceeding of the 2nd International Conference on Management and Muamalah (No. 2ndICoMM).

Isini, A., \& Karamoy, H. (2017). Evaluasi Penerapan Akuntansi Gadai Syariah (Rahn) Pada PT. Pegadaian (Persero) Cabang Manado, Jurnal Riset Ekonomi, Manajemen, Bisnis Dan Akuntansi, 5(2).

Muhammad, 2014, Manajemen Keuangan Syariah: Analisis fiqh \& Keuangan, UPP STIM YKPN, Yogyakarta.

Purbasari, I., \& Rahayu, S. (2017). Analisis Penerapan Akad Rahn (Gadai) dan Pengenaan Biaya Administrasi Rahn di Pegadaian Syariah (Studi Empiris di Kantor Cabang Pegadaian Syariah Pamekasan), Jurnal Hukum Ekonomi Islam, 1(1), 144-170. 
Rahman, L. A., \& Suprayogi, N. (2015). Analisis Kesesuaian Akuntansi Transaksi Gadai Emas Syariah Dengan PSAK dan Fatwa DSN MUI (Studi Kasus Praktik Gadai Emas di Pegadaian Syariah Surabaya), Jurnal Ekonomi Syariah Teori dan Terapan, 2(11).

Rahmawati, S. (2016). Pengaruh Interaksi Layanan, Lingkungan Fisik, Dan Hasil Pelayanan Terhadap Kepuasan Pelanggan Di Pegadaian Syariah Cabang Kebomas Gresik, (Doctoral Dissertation, UIN Sunan Ampel Surabaya).

Razak, A. A., Muhammad, F., Hussin, M. Y. M., Zainol, Z., \& Hadi, F. S. A. (2017). The Role of Ar-Rahn in Enhancing Financial Inclusion: A Structural Equation Modeling Approach, Jurnal Pengurusan (UKM Journal of Management), 50.

Setiawan, I. (2016). Penerapan Gadai Emas pada Bank Syariah Perspektif Hukum Ekonomi Islam, Jurnal al-Daulah, 6 .

Sofi'i, I. (2017). Analisis Transaksi Gadai Emas Dalam Perspektif Islam (Studi Kasus Pada BMT Al Muqrin Pondok Cabe Pamulang Banten), Keberlanjutan, 1(2), 94-112.

Sugiyono. (2014). Metode Penelitian Bisnis, Alfabeta, Bandung.

Yaya, R. (2014). Akuntansi Perbankan Syariah: Teori Dan Praktik Kontemporer, Salemba Empat, Jakarta. 